\title{
Does The John Bates Clark Medal Boost Subsequent Productivity And Citation Success?
}

\author{
Ho Fai Chan, Bruno S. Frey, Jana Gallus, and Benno Torgler*
}

(this version March 1, 2013)

\begin{abstract}
Despite the social importance of awards, they have been largely disregarded by academic research in economics. This paper investigates whether a specific, yet important, award in economics, the John Bates Clark Medal, raises recipients' subsequent research activity and status compared to a synthetic control group of nonrecipient scholars with similar previous research performance. We find evidence of positive incentive and status effects that raise both productivity and citation levels.
\end{abstract}

JEL classifications: A13, C23, M52

Keywords: Awards, Incentives, Research, John Bates Clark Medal, Synthetic control method

\footnotetext{
* Ho Fai Chan: Queensland Behavioural Economics Group (QuBE), School of Economics and Finance, Queensland University of Technology (Email: hofai.chan@qut.edu.au); Bruno S. Frey: Warwick Business School, University of Warwick and Department of Economics, Zeppelin University (Email: bruno.frey@econ.uzh.ch); Jana Gallus: Department of Economics, University of Zurich (Email: jana.gallus@econ.uzh.ch); Benno Torgler: Queensland Behavioural Economics Group (QuBE), School of Economics and Finance, Queensland University of Technology, and EBS Business School, EBS Universität für Wirtschaft und Recht. Frey and Torgler: Center for Research in Economics, Management and the Arts (CREMA). Please address all correspondence to Benno Torgler: benno.torgler@qut.edu.au.

We are thankful for comments by [will be added later].
} 


\section{Introduction}

The use of awards as both an incentive and a reward is universal. Government systems, from monarchies to republics, democracies to dictatorships, bestow awards to honor outstanding people. Besides the well-known state orders and medals, there is a plethora of additional awards, including prizes, titles, and decorations. Their bestowal has a long history, dating back to at least the Greek drama and arts competitions in sixth century BC. Of no less renown are the medieval architecture competitions (English 2005) ${ }^{1}$. Today, the United States (US) Congress and the President both bestow civilian medals, most notably the Congressional Gold Medal (established in 1776) and the Presidential Medal of Freedom (established in 1945). There is also a very large number of awards in the military sector; prominent examples being the Purple Heart and the Bronze and Silver Stars (Cowen, 2000: 93). Former communist countries, most notably the Soviet Union and the German Democratic Republic, are known for the abundance of orders (such as the Order of the Badge of Honor), medals, and titles (for instance, Mother Heroine), which their leaders bestowed on their citizens. Beyond politics,

\footnotetext{
${ }^{1}$ A good example can be found in Bramly's biography on Leonardo da Vinci. Leonardo was keen to make the bronze cathedral doors of Piacenza Cathedral. A document draft letter left by Leonardo written in the third person has led to speculations "whether he was not writing his own name but rather counting on some influential acquaintance to sign and send the letter on his behalf - not a very honest tactic, but a common one at the time, and employed here with some humor" (Bramly, 1988: 250). The letter starts with "Magnificent commissioners of the works, having learned that Your Excellencies have decided to erect certain great works in bronze, I propose to offer you some advice about this. First of all, take care not to entrust the commission so hastily as to fail to make a good choice both of master and subject. I cannot help feeling some irritation when I think of the individuals who have conveyed to you their desire to embark on such an enterprise without bothering to ascertain whether they are really capable of doing it, to say the least. One is a potter, another an armorer, a third is a bell founder and another a maker of bell clappers; there is even a bombardier among them... Open your eyes and try to assure yourself that your money will not serve to buy your own shame" (pp. 250-251). The letter then ends: "No one is qualified - believe me - apart from Leonardo the Florentine, who is now making Duke Francesco's bronze horse, and whom one need not suggest, since he has enough work for a lifetime; and I even doubt, so huge is his enterprise, that he will ever finish it" (p. 251). Bramly then notes that Leonardo was dissatisfied with the end and rewrote it: "There is the man his lordship called from Florence to do this work, who is a worthy master, but he has so much to do that he will never finish it" (p. 251).
} 
awards also assume a central role in the arts, culture, sports, and the media ${ }^{2}$. Prominent examples can be found in film (the Academy Awards), music (the Grammy Awards), and in literature (the Booker Prize, the Prix Goncourt, and the Pulitzer Prize).

Even in the corporate sector, where the only valid currency is supposedly money, much importance is attached to titles, such as Manager of the Year (Bielby and Baron, 1986; Malmendier and Tate, 2009; Wade et al., 2006), and many companies use formal recognition programs to honor their most valued employees (see, e.g., Magnus, 1981; Nelson, 2005). Academies and scientific institutions equally rely on a differentiated and extensive system of awards, with titles such as honorary doctor or senator. Most renowned are the Nobel Prizes (see Mazloumian et al., 2011) and the Fields Medal in mathematics. Many prestigious fellowships exist in scientific societies (e.g., in the American Academy of Arts and Sciences or in the Econometric Society ${ }^{3}$ ). Each year, the American Economic Association (AEA) elects Distinguished Fellows, as well as Foreign Honorary Members. It also recognizes a Best Paper Award for papers published in each of the four Association Journals (Applied, Economic Policy, Macro, and Micro).

Moreover, the American Economic Association awards the John Bates Clark Medal to a scholar under the age of 40 "who is judged to have made the most significant contribution to economic thought and knowledge." The John Bates Clark Medal was awarded biennially from 1947 to 2009, and annually from 2010 onwards. Many of its recipients go on to become Nobel Laureates. Of the 34 scholars who have been honored with the Clark Medal, 12 have subsequently won the Nobel Prize.

The social importance of such awards notwithstanding, academic research (outside the field of history) has largely disregarded them; partly, perhaps, because their infungibility raises doubts about their motivational

\footnotetext{
${ }^{2}$ See, for example, Ginsburgh and van Ours (2003), Holden (1993), Levy (1987).

${ }^{3}$ See the analysis by Hamermesh and Schmidt (2003) on the determinants of Econometric Society Fellowship elections.
} 
efficacy compared to such superior incentives as monetary compensation (Baker, Jensen, and Murphy, 1988; Holmstrom and Milgrom, 1994). Likewise, the fact that they cannot be consumed might make them of little interest to recipients, which would imply that they do not actually lead to superior performance. Another possible reason for the neglect is that awards could be valued merely for the increased future earnings they induce. For example, in the entertainment industry, Oscar recipients profit from large increases in their subsequent incomes (Nelson et al., 2001). However, there is research suggesting that the value of awards goes over and above the monetary benefits. As has been shown, individuals value status and are willing to give up financial gain to obtain it (Huberman, Loch and Öncüler, 2004). They accord value to awards as producers of status.

This paper explores the above-mentioned possibilities by focusing on a specific yet important award, the John Bates Clark Medal. It compares award recipients (the treatment group) to a control group of non-recipient scholars with similar previous research performance. The paper assess whether the award subsequently raises research activity and benefits the beholder via increased professional status by measuring publications and citations of publications that were published before the award conferral. Most particularly, by constructing a synthetic group of economists, we are able to distinguish whether the bestowal of the Clark Medal simply reflects the past activity of particularly gifted young economists or whether it also raises productivity thereafter. We find that the latter is indeed the case-and to a considerable degree. We also explore a status or "Matthew" effect - the phenomenon that success breeds success-referenced in Merton's observations of a "misallocation of credit for scientific work [...and the] accruing of greater increments of recognition for particular scientific contributions to scientists of considerable repute" (Merton, 1973: 445-446). We find that the John Bates Clark Medal heightens the visibility of articles published by its recipients. For Clark medalists, each article published before receiving the medal 
subsequently draws more citations compared to articles published by scholars in the synthetic control group of non-recipients. Based on these results, we conclude that awards in general may have both a positive productivity and a status effect.

The remainder of the paper is organized as follows: Section 2 discusses the existing literature on awards, Section 3 outlines the empirical research strategy, and Section 4 describes the data and the construction of the synthetic group of non-recipient economists. Section 5 then reports the econometric estimates, followed by a robustness check in Section 6. Section 7 presents our concluding remarks.

\section{Relevant Awards Literature}

The existing literature on awards is extensive (see Frey, 2005). However, most of it focuses on a descriptive approach to particular honors, for instance the Order of the Garter (Begent and Chesshyre, 1999) or the Order of Merit (Martin, 2007). Phillips (2004) and the Report of the House of Commons (2004) provide ample discussion and some data on orders in Great Britain. Specific aspects of awards in the arts and culture are analyzed in Ginsburgh (2003, 2005) and Simonton (2004), dealing for instance with the Academy Awards (Oscars) in film, the Booker Prize in literature, and the Eurovision Song Contest. Ginsburgh and Van Ours (2003), and Glejser and Heyndels (2001) study the Queen Elisabeth Music Competition, one of the most important international competitions in classical music. In the field of science, Coupé (2013) analyzes best paper prizes given by economics and finance journals. Hamermesh and Schmidt (2003) study the determinants of Econometric Society Fellowship elections. Assessments of the more general phenomenon of awards can be found in sociology (e.g., Bourdieu, 1979; Braudy, 1986; Elster, 1983; or Walzer, 1983).

With the exception of the path-breaking contribution by Hansen and Weisbrod (1972) and the few studies referenced above, economists have 
largely neglected awards as a research topic. Among the few who have since followed suit are Besley (2005), Frey (2006, 2007), Frey and Gallus (2013), Gavrila et al. (2005), Kosfeld and Neckermann (2011), Malmendier and Tate (2009), and Neckermann, Cueni and Frey (2012). Some economists have studied related issues - examples are Akerlof (1976) on reputation; Frank (1985), Frank and Cook (1995), and Scitovsky (1976) on positional goods; Nalebuff and Stiglitz (2001) on incentives; and Auriol and Renault (2008) on social status. Closely related, albeit not emanating from the field of economics, is the work by Brennan and Pettit (2004) on esteem.

\section{Empirical Strategy}

The central aims of this paper are to assess the effect on work performance of receiving or anticipating the John Bates Clark Medal, and to evaluate how this award affects future (citation) success. Academia provides an especially fruitful real-world laboratory setting for analyzing status shocks because of three characteristics: First, it is easy to distinguish between individual producers (scientists) and their products (scientific articles); second, the flow of citations serves as a metric for status effects; and third, status shocks take the form of prizes/awards (Azoulay, Stuart, and Wang, 2011: 9-10). The John Bates Clark Medal, specifically, provides early recognition and status that could enhance self-confidence and thus post-award publication performance. Merton, for example, refers to Thomas Henry Huxley's apparent doubts about his own capacities: "the only use of honors is as an antidote to such fits of the 'blue devils'... there are times when grave doubts overshadow my mind, and then such testimony as this restores my self-confidence" (Merton, 1973: 437). He also cites Czeslaw Milosz's argument that "[h]onorific awards should not be regarded only psychologically ... as providing incentives for excellent work. They also serve a social function, by testifying to the merit of kinds of excellence that might otherwise be regarded as having small significance in 
society. Recognition may counter tendencies of the intellectual to feel himself alienated from his society" (Merton, 1973: 438).

More recent studies use experimental approaches to study awards as incentive mechanisms in order to handle causality issues. Kosfeld and Neckermann (2011), for example, gauge the effect of symbolic awards on work performance by studying the work performance of students in an international non-governmental organization who are exposed to a social recognition environment in which the best performing student receives a nonmonetary award. On average, the work performance of the treatment group (recipients) is $12 \%$ higher than that of the control group (non-recipients). By using students, a relatively homogeneous group of subjects, the authors are able to show that symbolic awards provide an incentive for students to put in more work effort. In the same vein, Neckermann, Cueni, and Frey (2012) use 2004 to 2007 work performance rating data of 155 credit card service call centre agents to assess the effect of a non-performance based award on winners' ex-post performance. They find that the award produces short-term performance enhancement in both the winners and their work group. In an earlier study, Markham, Scott, and McKee (2002) use work attendance data for 1,110 workers in four garment factories to compare attendance rates at a factory that has a social recognition program with that of another plant with no such intervention. They find that work attendance is higher in the presence of social recognition programs that publicly praise employees with perfect attendance records.

In our study, however, the quasi-natural experiment using the John Bates Clark Medal recipients as the treatment group makes it more difficult to identify any causal effect. That is, having been judged as having higher performance than other researchers, award recipients are a highly selected group (i.e., superstars), meaning that the non-random assignment of the treatment group may raise such issues as treatment/control group comparability. Hence, to build a control group of non-recipient researchers 
with similar profiles (i.e., similar publication and citation performance), we employ the data-driven statistical method that Abadie and Gardeazabal (2003) developed to construct a synthetic control region for estimating the economic cost of the terrorist conflict in Spain's Basque Country. In their model, the counterfactuality is a weighted combination of other Spanish regions whose relevant economic variables are closest to those of the Basque Country before the outset of terrorist activity. Since then, other studies have used the synthetic control method to assess the effect of a policy intervention or economic shock. Abadie, Diamond, and Hainmueller (2010), for example, analyze the effect of a tobacco control program on tobacco consumption in California by using other states to create a "synthetic California." Likewise, Campos and Kinoshita (2010) and Sanso-Navarro (2011) adopt the same technique to investigate the effect of the structural reforms in Russia and Argentina, and of the United Kingdom (UK) not adopting the Euro on foreign direct investment inflow, respectively. Cavallo et al. (2010) apply the method in a cross-country study to estimate the economic cost of a natural disaster, while other studies employ it to assess the effect of terrorism or crime (Abadie and Diamond, 2008; Montalvo, 2011; Nilakantan and Singhal, 2012; Pinotti, 2011) or of macro-policy interventions on economic growth (Abadie, Diamond, and Hainmueller, 2012; Billmeier and Nannicini, 2011; Dhungana, 2011; Liou and Musgrave, 2012).

We exploit this synthetic control method to select a suitable control group for the John Bates Clark Medal recipients and to assess the effect of this award on research productivity and status. The aim is to select a counterfactual group of non-recipient economists who share similar time-invariant academic characteristics and a similar ex-ante research output (i.e., before the winner receives the award). To this end, we first derive the individual academic lifecycle performance for all researchers across both publications and citations. We then use the synthetic control method to choose a group of 
researchers, such that their weighted combination is as close as possible to the ex-ante performance of the John Bates Clark medalists (JBCM).

Such an approach is also used in a recent study by Azoulay, Stuart, and Wang (2011), who assess the effect of status changes on researchers' citation performance. More specifically, they look at the event of life scientists' appointment as investigators at the Howard Hughes Medical Institute (HHMI), a highly regarded institution in the biomedical research field whose selection committee consists mostly of National Academy of Sciences members. They exploit the effect of this positive status shock on post-appointment citation performance by using coarsened exact matching (CEM) (Iacus, King, and Porro, 2011), a non-parametric matching method, to select articles with similar citation trajectories and then compare those published by HHMI investigators before their appointment with those written by other high-quality, but nonappointed, scientists. The CEM method identifies potential control articles based on the following shared characteristics with the HHMI papers: (1) year of publication, (2) journal, (3) number of authors, (4) author position in the authorship list, and (5) cumulative number of citations to the article before the HHMI appointment. The control article is selected if the sum of squared differences in citation counts between the treated and control articles from the year of publication until the year before appointment is minimized. They find evidence of a moderate post-appointment citation boost on HHMI articles published before the appointment. They also observe a very slight increase in the citation rate in the first year after the appointment with a gradual decrease over subsequent years.

Similar to that of Azoulay, Stuart, and Wang (2011), our control group selection relies on how closely the trajectories of the overall number of publications or citations between JBCM and the control group are matched before the medal is awarded. There are, however, three notable differences between their study and ours: First, instead of using article-level data, we focus on the researcher level by looking not only at a status effect via citations 
but also at work productivity; second, whereas their HHMI subfields are quite broad, our group of economists is relatively homogeneous; and third, we use a weighted combination of a few researchers, thereby ensuring that the control group has the closest match to the treatment group. We construct one control group for each JBCM. Once the entire control group is chosen, we present a set of graphs on publication output and citation success for the JBCM group versus the "synthetic" non-medalist group, and compare their academic lifecycle performance in the post-award period. If the performance trajectory of JBCM deviates from the counterfactuals, we conjecture that such differences are due to the effect of receiving the Clark Medal.

\section{Synthetic Group: Data and Construction}

\section{A. Publication and Citation Data}

Our goal is to use the publication and citation lifecycle profiles of researchers to create a dataset of elite economists and choose the most similar possible control group for the JBCM. To do so, we rely on the publication content data of the top 23 economics and finance journals listed on the Web of Science, an online academic citation index (see Table A1 in the Appendix for the founding year and publication statistics for each journal). We decided on which journals to include based on the journal rankings given in Conley et al. (forthcoming), Kalaitzidakis, Mamuneas, and Stengos (2011), Koczy and Strobel (2010), Kodrzycki and Yu (2006), Liebowitz and Palmer (1984), Palacios-Huerta and Volij (2004), and Ritzberger (2008) for the top 23 economics and finance journals. Each journal selected appears at least once in the top 10 position of any ranking (see Table A2 in the Appendix), with American Economic Review (AER), Econometrica, and the Journal of Political Economy (JPE) ranking highest four times, twice, and once, respectively (given a weight of 1 in these cases). Other journals are assigned a value smaller than 1, expressed as a fraction of the highest-quality journal. We then use the average ranking value 
of all the journals' reported rankings as a quality adjustment index (see Table A3 in the Appendix for the details of these ranking methods).

To capture all publications by both the JBCM and the potential control group, we record the publication and yearly citation information on articles available in the selected journals up until December $2011^{4}$. The dataset developed consists of 26,523 unique researchers and 59,690 journal articles, of which 1,321 are published by the 34 JBCM. Correctly identifying all publications for a unique researcher, however, is challenging ${ }^{5}$, so we also conducted a search on the scholars' academic backgrounds. One important criterion for constructing a suitable control group of JBCM is to control for the quality of the education received. We therefore used the rankings of economics departments cited in Coupé (2003) to identify economists who received their doctoral degrees at institutions similar to, or the same as, those of the medalists. These data are obtained from various sources: ProQuest Dissertations \& Theses (PQDT), researchers' curricula vitaes, university records, and Google searches. When we limit our analysis using the $\mathrm{PhD}$ ranking information, the number of researchers drops to 10,093. On the one hand, by imposing this limitation, we effectively exclude most researchers who are based outside the US and who might have a similar publication profile as the JBCM. On the other hand, introducing the $\mathrm{PhD}$ ranking information increases the comparability between the treatment and control

\footnotetext{
${ }^{4}$ These data were obtained between February and May 2012, and exclude publication and citation records after December 2011. The publication information dataset includes title, volume, issue, beginning and ending page numbers, the list of authors, their corresponding author position, and the type of publication activity. We do not exclude self-citations, but do exclude book reviews, and conference and proceedings papers, as well as post-publication activity, such as comments, replies, and corrections.

${ }^{5}$ This difficulty depends on the commonness of the researcher's name and the consistency of his or her publication name across journals over time. We unify researchers' publication names by the similarity of the authors' first and middle name (e.g., same initials, allowing for spelling mistakes) in entries that share the same surname. To avoid false unification, we carefully separate two distinct researchers if they share the same surname but are linked to two distinct publication distributions more than ten years apart. We also verify manually whether the two groups of articles were written by two researchers under the same name or whether the researcher shortened his or her first name (e.g., Dan and Daniel, Dave and David, or Ben and Benjamin).
} 
groups. Hence, we follow the rule that, unless there is a substantial improvement in the fitting or the pre-treatment variables, we always choose to impose the $\mathrm{PhD}$ ranking criterion/limitation.

\section{B. Academic Performance Proxies}

Both the various proxies for researcher productivity-including number and quality of publications - and citations as a quality proxy (Blair, Cottle, and Wallace, 1986; Diamond, 1984, 1989; Hamermesh, Johnson, and Weisbrod, 1982; Johnston, Piatti, and Torgler, forthcoming; Stigler and Friedland, 1975, 1979; Sutter and Kocher, 2001) are widely employed as tools for evaluating performance (e.g., Conroy, Dusansky, Drukker, and Kildegaard, 1995; Hansen, Weisbrod, and Strauss, 1978; Medoff and Abraham, 1981; Tuckman and Leahey, 1975). Nevertheless, using citations as a proxy for quality is not without problems (for recent discussions, see Coupé, Ginsburgh, and Noury, 2010, and Torgler and Piatti, 2011). For example, fields with a larger research population attract more citations (Arrow et al., 2011; Cole and Cole, 1971), and citations can be driven by fashion (van Dalen and Klamer, 2005). Nevertheless, there is evidence that citations are highly correlated with the assessed quality of papers (Lindsey, 1980), and with peer ratings of eminence or perceived scientific significance (Albert, 1975). As already mentioned, they also serve as a valuable metric for evaluating the effects of status (Azoulay, Stuart, and Wang, 2011).

In this paper, we evaluate researcher productivity based on the number of publications (quality adjusted) and impact based on citations per publication, controlling for the quality of the publication (obtained by dividing the cumulative citations by the cumulative number of publications). To control for co-author influence, we divide both the publication and citation counts by the number of authors for each article (for a discussion, see Hollis, 2001; Lindsey, 1980; Long and McGinnis, 1982). 
We obtain the list of JBCM from the American Economic Association and then identify all publications by the $34 \mathrm{JBCM}$ in the dataset. On average, based on the list of top journals the year before the award is announced, JBCM published 17.7 articles. The average time length from the medalists' first publishing year (hereafter, debut year) to the year they receive the award (award year) is 12.53 years. The average time length from the year they received their $\mathrm{PhD}(\mathrm{PhD}$ year) to the award year is 11.24 years except for Kenneth E. Boulding, who did not earn a doctorate. Three JBCM received their doctoral degrees from universities outside the US, two from the UK (Oxford University and London School of Economics), and one from the University of Amsterdam. Ten medalists earned their PhD from MIT and seven from Harvard University. The average age at which a medalist receives the Clark Medal is 37.6. In our analysis, however, we only focus on the first 27 JBCM (i.e., up to 2001) in order to assess post-award performance. The list of the medalist is presented in Table A4 in the Appendix.

\section{Construction of the Synthetic Group}

The ideal method for assessing the impact of the John Bates Clark Medal on a researcher's publication performance, whether in quantity (number of publications) or quality (citation counts), is to compare the actual Clark medalist to researchers who have similar ex-ante research performance. We therefore create a group of "synthetic" counterfactuals using a weighted combination of researchers that best resemble the academic lifecycle of the corresponding medalists before receiving the award. First, we limit our potential "donor" pool for the synthetic group to researchers with a similar academic background to the JBCM of interest. For each JBCM, we use researchers whose debut years are no more than five years from that of the JBCM. For example, according to our database, Gary S. Becker published his first article, "A Note on Multi-Country Trade," in the AER in 1952. Hence, in 
constructing his corresponding control group, we exclude researchers who published their first article in our selected journals before 1947 or after 1957. This exclusion allows us to account for potential cohort effects. We also impose a limitation that is based on the quality of the institution at which the $\mathrm{PhD}$ was earned, by excluding researchers who received their doctoral degrees from institutions that are more than three ranking positions away (above or below) from that of the JBCM in Coupe (2003) ${ }^{6}$. Lastly, we define two sets of potential donor pools for each JBCM. In the first one, we also include researchers who later become John Bates Clark Medalists, thereby avoiding a selection based on individual characteristics from ex-post information. However, if awards lead to an increase in productivity and status, the inclusion of researchers who later become Clark Medalists could result in lower-bound estimates. We therefore develop a second donor pool that excludes all JBCM from the pool. However, in this case we compare JBCM's performance with that of researchers never awarded the medal. This approach could induce an upward bias resulting from a potential selection bias.

If $J_{i}$ is the number of non-award winning potential donors of the synthetic group for $\mathrm{JBCM} i \in 1, \ldots, 27$, then a $J_{i} \times 1$ weight vector $\boldsymbol{W}_{\boldsymbol{i}}=$ $\left(w_{1}, \ldots, w_{J_{i}}\right)^{\prime}$ defines the contribution of each researcher in constructing the synthetic non-medalist. To ensure no extrapolation, all weights are nonnegative and sum to one; that is, $w_{j} \geq 0$ and $w_{1}+\cdots+w_{J_{i}}=1$. We obtain $\boldsymbol{W}_{\boldsymbol{i}}^{*}$, such that

$$
\boldsymbol{W}_{\boldsymbol{i}}^{*}=\underset{w}{\operatorname{argmin}}\left(\boldsymbol{X}_{J B C, \boldsymbol{i}}-\boldsymbol{X}_{\boldsymbol{S C}, \boldsymbol{i}} \boldsymbol{W}_{\boldsymbol{i}}\right)^{\prime}\left(\boldsymbol{X}_{J B C, \boldsymbol{i}}-\boldsymbol{X}_{\boldsymbol{S C}, \boldsymbol{i}} \boldsymbol{W}_{\boldsymbol{i}}\right),
$$

where $\boldsymbol{X}_{\boldsymbol{J} \boldsymbol{B}, \boldsymbol{i}}$ is a $T \times 1$ vector of medalist $i$ 's pre-award values of academic performance predictors (i.e., pre-award publication and citation measures),

\footnotetext{
${ }^{6}$ For Kenneth E. Boulding, we impose no limitations on his educational background. Always seven institutions have been considered. For example, for a JBCM who obtained his PhD from an institution with a ranking position that is less than or equal to 3, we always consider researchers who received their $\mathrm{PhD}$ in a top 7 institution. On the other hand, if a JBCM has a $\mathrm{PhD}$ from an institution ranked at position 17, we consider all researchers who received their $\mathrm{PhD}$ in institutions ranked between position 14 and 20.
} 
$\boldsymbol{X}_{\boldsymbol{S C}, \boldsymbol{i}}$ is a $T \times J_{i}$ matrix of the same measures for the $J$ corresponding potential donors, and $T$ is length of the matching period. The two vectors $\boldsymbol{X}_{\boldsymbol{J B C}, \boldsymbol{i}}$ and $\boldsymbol{X}_{\boldsymbol{S C}, \boldsymbol{i}}$ are matched based on the same phase in their academic lifecycle such that $T$ refers to the performance of JBCM ten years preceding the year of award conferral. To account for the possibility that the award committee may have information on forthcoming articles, we include the publication performance of the year of award in the matching process.

Our method differs from that used by Abadie and Gardeazabal (2003) in that they include predictors other than the outcome variables and impose a data-driven matrix $\boldsymbol{V}$ in the minimization equation that assigns weights to each predictor such that the outcome variable has the closest match. In our matching procedure, in contrast, we focus solely on the outcome variables in the pre-treatment period and use specific variables to pre-select researchers into the donor pool; namely, the debut year in the top journals, the year the $\mathrm{PhD}$ was obtained, and the quality of the $\mathrm{PhD}$ institution.

\section{Econometric Estimates}

We present the findings in a set of graphs that compare the average

performance of the medalists $\bar{Y}_{J B C}=\sum_{i=1}^{I} \frac{Y_{J B C, i}}{I}$ against that of the control $\operatorname{group} \bar{Y}_{S C}=\sum_{i=1}^{I} \frac{Y_{S C, i}}{I}, \quad$ where $Y_{S C, i}=\sum w_{i j} Y_{i j}$ for $j=1, \ldots, J$ for each medalist $i \in 1, \ldots, 27$. Here, the timeline is adjusted so that year 0 is the award year (indicated with a vertical line) for all medalists. First we show the performance from 20 years before, and 14 years after, the award year. This choice of post-award years is driven by the fact that 12 JBCM have also been awarded the Nobel Prize; most notably, Kenneth J. Arrow, who won the Nobel Prize 15 years after being awarded the Clark Medal. In those cases where we extend the post-award period (citation analysis), the observation is dropped from the sample (if the JBCM won the Nobel Prize during the time frame of 
observation). Otherwise, the citation pattern would be distorted by the status change induced by the Nobel Prize.

\section{A. Cumulative Publication Counts}

Figure 1 compares the average cumulative publication numbers for JBCM versus the two synthetic control groups $(\mathrm{SC})^{7}$. The dashed line (Synthetic Control Group 1) represents the synthetic control group from the potential donor pool that includes researchers who later become JBCM, while the dotted line (Synthetic Control Group 2) shows the performance of the control group that excludes any JBCM. Both approaches produce a similar gap between the synthetic group and the JBCM. For simplicity, we report the values of the former (Synthetic Control Group 1). It should be noted that in our case the synthetic control method uses, on average, 4.59 researchers $(\mathrm{SD}=$ 2.14) to construct the control group for each medalist. For instance, in the synthetic control group for Andrei Shleifer (who was awarded the Medal in 1999 and is therefore one of the most recent entries in our data set) comprises 7 distinguished economists in his synthetic group. Table A5 lists the names and the corresponding weights for each researcher. Moreover, in Figure B1 we show the publication performance of Andrei Shleifer and his synthetic group. In the post-award period considered, medalists publish on average 0.39 weighted articles each year, which is 1.72 times more than the synthetic control group (0.22). Hence, five years after the award, JBCM, on average, achieve 10.80 weighted publications, which is 1.92 more than the synthetic control group's 8.88 weighted publications. This difference between treatment and control group grows to 2.46 weighted publications ten years after award

\footnotetext{
${ }^{7}$ The control groups are chosen in such a way that the pre-award cumulative number of publication counts and the debut year are closest to the Clark medalists. We impose no limitation on $\mathrm{PhD}$ rankings because relaxing it produces more closely matched pre-award publication counts between the treatment and control group. For more recent Clark medalists - for example, 2001 winner Matthew Rabin - we observe only ten years of postaward performance (2001-2011), and only compare the medalist's performance with that of the corresponding control group if both have the same number of observable years. Because JBCM share the last observable year with their corresponding synthetic control group, the results are less influenced by observational dropouts.
} 
conferral, when JBCM and the synthetic control group have on average published 12.45 and 9.99 weighted articles, respectively.

Figure 1: NUMBER OF PUblicATIONS

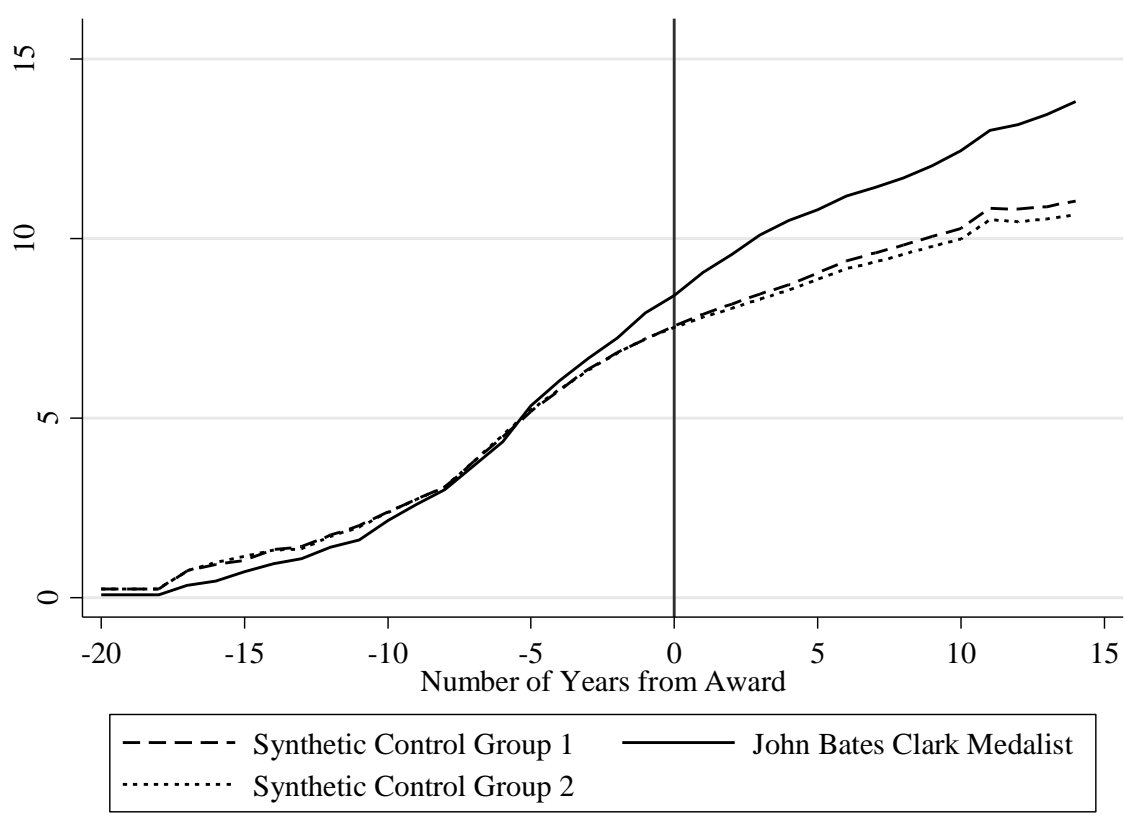

As can be seen in Figure 1, there is a small observable deviation even before JBCM receive the award. It is possible that once they are approaching the John Bates Clark Medal age restriction (i.e., the age of 40), JBCM work more intensively, perhaps in the hope of receiving such recognition. Given that the award does not go to unknowns, their (perceived) chances must have already been quite high, which would in turn stimulate a performance boost within a relatively short timeframe before the award. In fact, the first Clark medalist, Paul Samuelson, in his "Chasing the Bitch Goddess of Success," stresses the importance of earning professional recognition and respect: "Let me close with a few remarks on the motivation and rewards of scientists. Scientists are as avaricious and competitive as Smithian businessmen. The coin they seek is not apples, nuts, and yachts; nor is it the coin itself, or power as that term is 
ordinarily used. Scholars seek fame. The fame they seek, as I noted in my 1961 American Economic Association presidential address, is fame with their peers - the other scientists whom they respect and whose respect they strive for. The sociologist Robert K. Merton has documented what I call this dirty little secret in his book The Sociology of Science. I am no exception. Abraham Lincoln's law partner and biographer William Herndon observed that there was always a little clock of ambition ticking in the bosom of honest and whimsical Abe. No celebrity as a Newsweek columnist, no millions of cleverbegotten speculative gains, no power as the Svengali or Rasputin to the prince and president could count as a pennyweight in my balance of worth against the prospect of recognition for having contributed to the empire of science" (Samuelson, 2004: 60). Merton himself cites Selye's comments on such recognition: "Why is everybody so anxious to deny that he works for recognition?... All the scientists I know sufficiently well to judge (and I include myself in this group) are extremely anxious to have their work recognized and approved by others. Is it not below the dignity of an objective scientific mind to permit such a distortion of his true motives? Besides, what is there to be ashamed of?" (Merton, 1973: 341).

\section{B. Citation Counts per Publication}

In this section, we examine the effect of receiving the John Bates Clark Medal on citation success. In line with Azoulay, Stuart, and Wang (2011), we assess whether there is a significant difference between the treatment and control group in post-award citation counts per publication for publications that were published before the award was received. Exploring only published articles before the award allows us to isolate a potential "Matthew" effect. By using citation counts per publication, we can assess the average perceived impact of a scholar's work without the effect being subject to the upward bias of receiving more citations from publishing more articles. To construct the 
synthetic control group based on publication quality, we use the pre-award number of journal pages and the citations per publication as performance predictors, together with the debut year, $\mathrm{PhD}$ year, and $\mathrm{PhD}$ ranking of the researcher.

Figure 2 shows the average citation counts for articles published before the Clark Medal was received. Figure 3 shows the individual differences between JBCM and the synthetic group ${ }^{8}$ from ten years before to ten years after the award year. The dotted line shows the standard error of the differences among groups. As expected, receiving the John Bates Clark Medal has a positive and long-lasting effect on the citation counts of pre-award publications. We note in Figures 2 and 3 that the citation paths evolve similarly for both groups and the difference between the groups is very close to zero in the pre-award period, indicating a close match in the pre-award quality measure. The citation path then diverges once JBCM experience the status change at year 0 . On average, JBCM receive 18.35 citations for each article published before the award at year 5, and 32.12 at year 10, while the synthetic control group has only 12.27 and 18.1 citations per pre-award publication at years 5 and 10. In other words, compared to the synthetic control group, five and ten years after receiving the award, JBCM receive 6.08 and 14.02 more citations, respectively, for any article they had published before receiving the award. As Figure 3 shows, the divergence rate function of the two curves is relatively linear, with an average post-award slope of 1.39 after being horizontal beforehand. This means that, on average, the gap between the citations received by JBCM and the synthetic control group grows by 1.39 weighted citations per post-award year.

\footnotetext{
${ }^{8}$ Since the difference in SC1 and SC2 is not statistically significant, we only report SC1 from here onwards $(\mathrm{t}=0.02)$, for example, the cumulative citation counts at year 10 are equal to 18.09 and 18.14 respectively.
} 
Figure 2: CitATIONS PER PUblicAtion

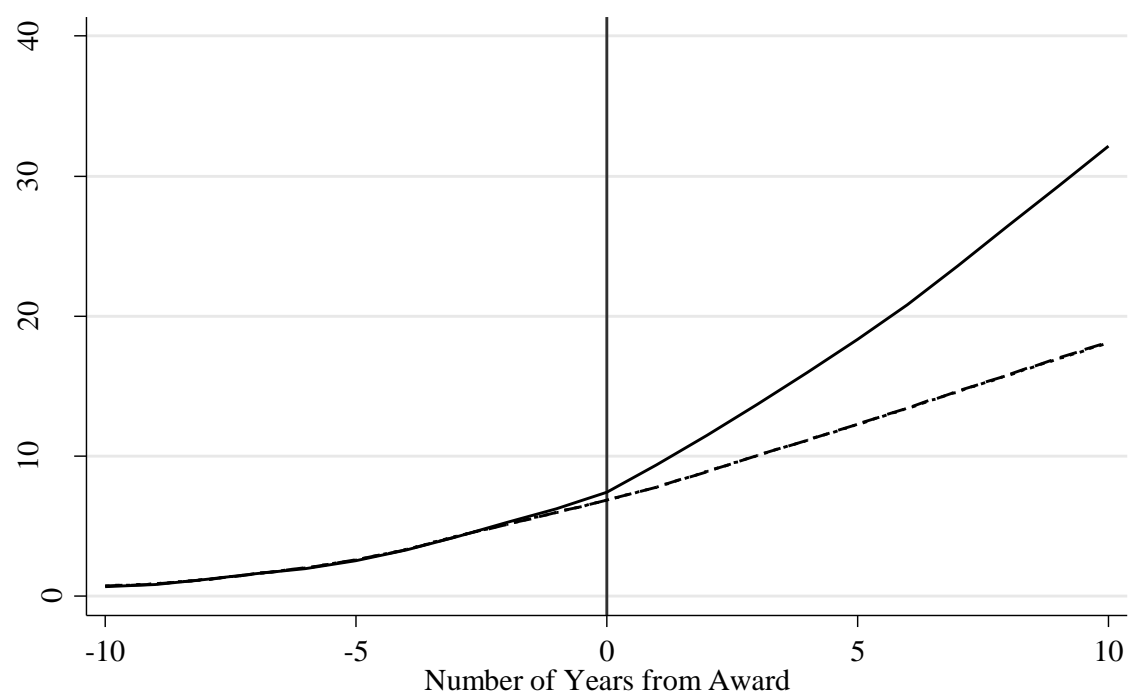

- - - - - Synthetic Control Group 1 John Bates Clark Medalist Synthetic Control Group 2

Figure 3: DifFERENCE IN CitATIONS PER PUblicATION

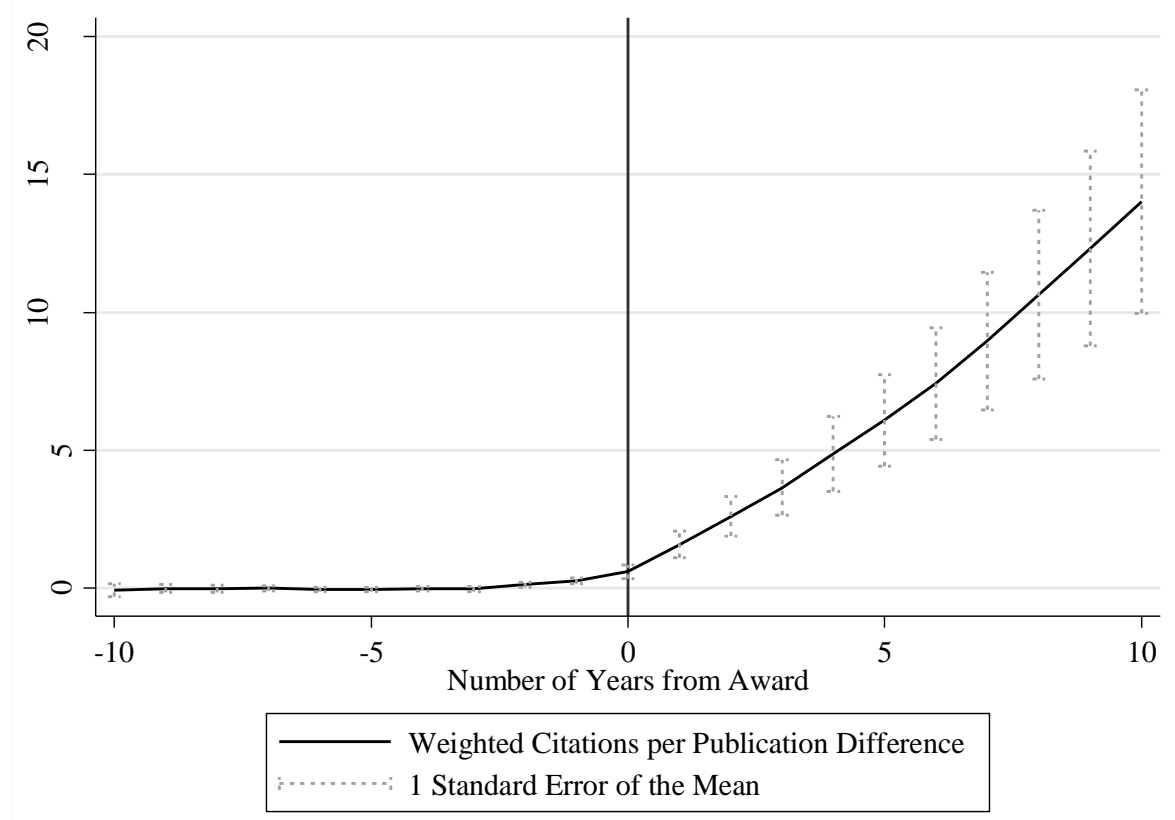


Rather than reporting further figures in which we extend the timeframe after the award, we present in Table 2 an overview of ten figures on post-award differences in citations per pre-award publication. Increasing the post-award period (from 11 to 20 years) shows the difference between the control and treatment groups in the later time periods. This extension of the post-award period reduces the number of medalists that can be included in the analysis. In all ten cases, the difference between the control group and the treatment group is statistically significant. The gap between both groups grows when exploring later post-award years, reaching the largest relative difference 19 years after the award (3.07 times more citations for JBCM). These numbers are a strong indicator of a status or "Matthew" effect.

TABLE 2: DifFERENCES In Post-Award CitATIONS PER PUbliCATION

\begin{tabular}{|c|c|c|c|c|c|c|}
\hline \multicolumn{7}{|l|}{ Post- } \\
\hline \multicolumn{3}{|l|}{ Award } & \multirow{2}{*}{$\begin{array}{l}\text { Value } \\
\text { Diff. }\end{array}$} & \multicolumn{2}{|l|}{ Relative } & \multirow[b]{2}{*}{ t-statistic } \\
\hline Years & $\mathrm{JBC}$ & $\mathrm{SC}$ & & Diff. & $\mathrm{N}$ & \\
\hline 11 & 31.16 & 18.24 & 12.92 & 1.94 & 26 & 3.54 \\
\hline 12 & 33.58 & 19.28 & 14.30 & 1.95 & 26 & 3.54 \\
\hline 13 & 34.16 & 18.77 & 15.39 & 2.03 & 25 & 3.25 \\
\hline 14 & 36.74 & 19.76 & 16.98 & 2.11 & 25 & 3.22 \\
\hline 15 & 37.32 & 20.47 & 16.86 & 2.13 & 24 & 2.90 \\
\hline 16 & 39.88 & 21.40 & 18.48 & 2.15 & 24 & 2.87 \\
\hline 17 & 42.14 & 21.93 & 20.21 & 2.25 & 23 & 2.73 \\
\hline 18 & 45.11 & 22.72 & 22.39 & 2.35 & 23 & 2.72 \\
\hline 19 & 48.43 & 21.92 & 26.51 & 2.70 & 22 & 2.78 \\
\hline 20 & 51.98 & 22.59 & 29.39 & 3.07 & 22 & 2.73 \\
\hline Average & & & 19.34 & 2.27 & & \\
\hline
\end{tabular}


In Figure 4, we show that the absolute difference in citations per pre-award publication is higher for JBCM in the time period between 1977 and 2001 (Panel B) than in the period between 1947 and 1975 (Panel A). In Panel A, the citation gap ten years after receiving the award is only 4.38, whereas for the more recent JBCM, the gap equals 24.42. This increase in the gap between the control group and the JBCM is in line with a generally much higher level of citations in the second period. This explains why the relative difference is larger for the period between 1947 and 1975. In year 10, JBCM have a 81\% higher citation rate than the synthetic group in Panel A and 76.9\% in Panel B. Interestingly, Piatti (2012) shows that the citation inequality among papers in AER decreased in the last 60 years. Such a result is consistent with our findings.

Panel A also shows that the citation counts for JBCM are 2.28 times higher than the synthetic control group in year 25. Thus, the gap remains considerable. The "visibility function" of awards could be crucial in explaining this stark contrast between treatment and control groups. Academia is faced with a "battle of attention" due to an immoderate number of papers produced per year. Since the sheer number of researchers and articles make it difficult to assess quality, awards can assume an important signaling function (Frey and Gallus, 2013). The copious output could lead scholars to rely on simple heuristics for information gathering and might explain why economists are attracted by the fame of JBCM. 
Figure 4: Citations Per Publication By PERIOD ${ }^{9}$

PANEL A: 1947-1975 JBCM

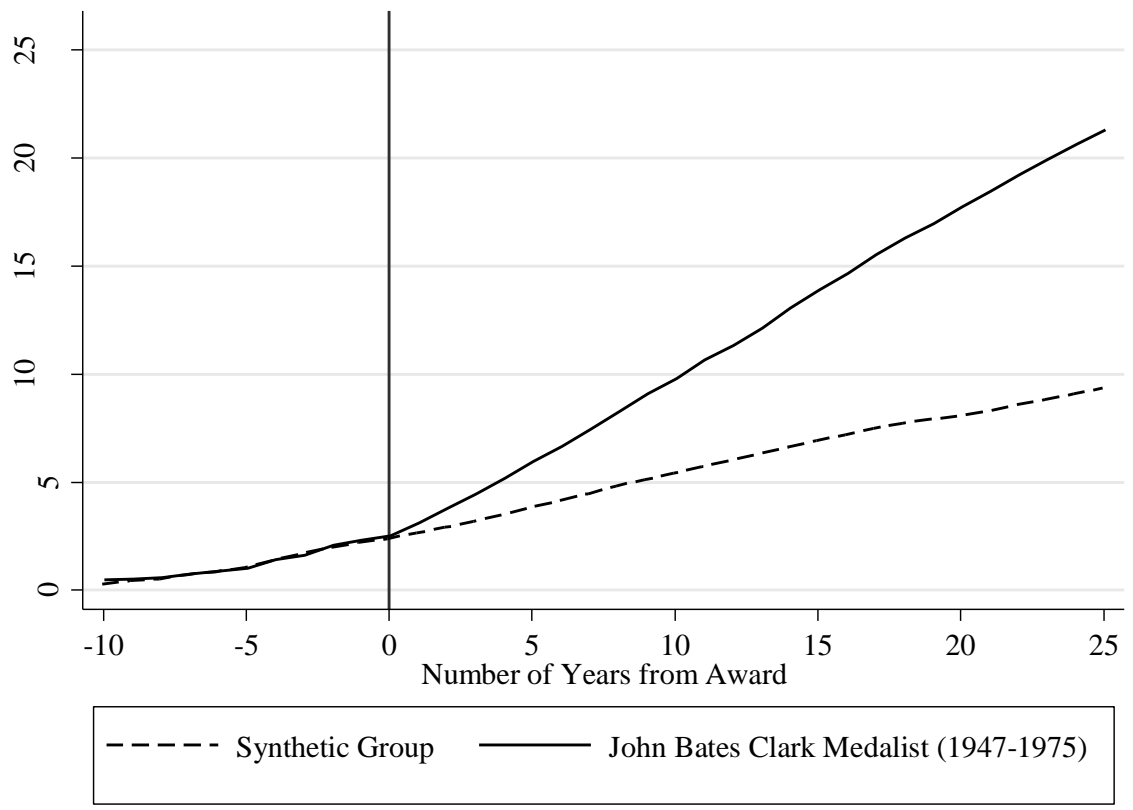

PANEL B: 1977-2001 JBCM

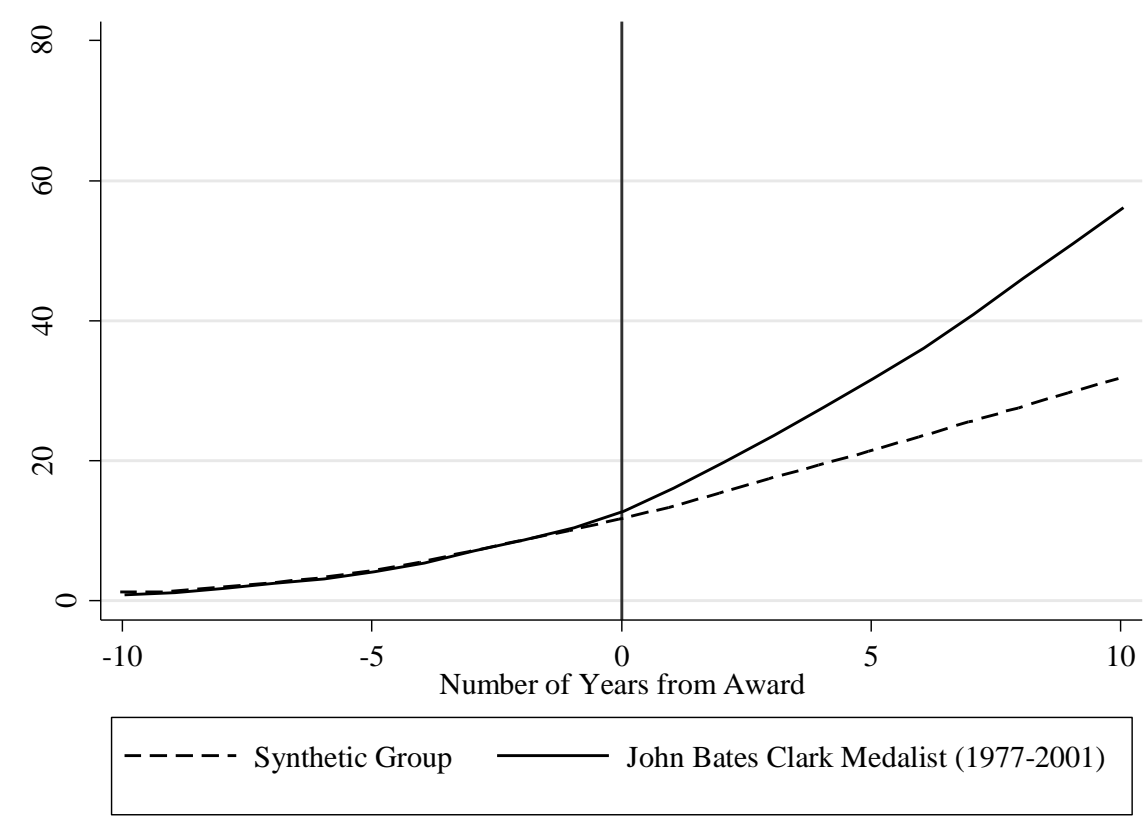

${ }^{9}$ One should recall that the John Bates Clark Medal was awarded biennially from 1947 to 2009. Therefore, 1976 was not an award year. 


\section{Robustness Check}

In this section, we assess the robustness of our main results by varying the measurement proxy and the method by which we select the control group. First, we use the weighted number of journal pages as the measure of productivity instead of the publication head counts. We find that the relative page difference between the synthetic control group and treatment group over the post-award period is not significantly different from relative publication difference $(t=0.84)$. For instance, after 10 years JBMC publish 1.22 times more pages than the control group which is similar to the reported relative publication performance (1.25 times more publications). Then, we limit the control group to only Fellows of the Econometric Society (ES). Nearly 900 (899) individuals have so far been awarded fellowship (for an overview, see Chan and Torgler, 2012). All John Bates Clark Medal recipients have been elected as Fellows of the ES (except Kenneth E. Boulding and Emmanuel Saez). Most JBCM have been appointed as Fellows before obtaining the Medal. We are able to use data of 858 Fellows to build the synthetic group. We rely solely on the debut year and the pre-treatment citation and publication performance (without controlling for the quality of the education received). The results using both measurements (cumulative publication counts and citations per publication) are reported in Appendix B2. Compared to the previous results, we observe a smaller gap between the JBCM and the ES synthetic control group. For example, in year 10, the difference in the number of publications between the ES synthetic control group and the JBCM is 1.52 (weighted) articles instead of 2.46 (previous synthetic group). A small reduction in the gap can also be found for citations per publication (from 14.03 to 10.1 ).

\section{Conclusion}

Awarding prizes, medals, and trophies has a long history. Science, along with many other institutions, has developed a system to allocate rewards to those 
who excel. This paper investigates whether the John Bates Clark Medal, the preeminent token of recognition among American economists below the age of 40, raises the subsequent research activity and citation-based status of award recipients (the treatment group) compared to non-recipient scholars with similar previous research performance (the control group). Specifically, we construct a group of "synthetic" counterfactuals (see Abadie and Gardeazabal, 2003) to the John Bates Clark medalists using a weighted combination of non-recipient researchers that best resemble the pre-award academic lifecycle of the corresponding medalists. We are thus able to distinguish whether receiving the Clark Medal merely reflects the activity of particularly gifted young economists or whether it actually raises scholarly productivity and status.

We find that the latter is indeed the case - and to a considerable degree. Our results indicate a positive effect on productivity after receiving the award. We also note a strong post-award citation gap that shows no sign of diminishing over time. On average, at five years after the award conferral, Clark medalists have 1.92 more weighted publications than the synthetic control group. Furthermore, Clark medalists attract 18.35 citations per publication, whereas the control group attracts 12.27, demonstrating a difference of 6.08 citations per pre-award publication. After another five years, the difference in weighted publications has grown to 2.46, whereas the gap in citations per article amounts to 14.02. Ten years after the award conferral, Clark medalists and the synthetic control group respectively attract 32.12 and 18.1 citations per publication on all articles published before the award.

Assuming that, at the time of the Clark Medal's conferral, recipients and the control group had the same number of publications (17.7), after five years, a recipient on average accumulates 325 citations for these publications, i.e. $50 \%$ more than the synthetic control group with 217 citations. Ten years after conferral of the Clark Medal, the recipients have 569 citations on those 
same publications, compared to 320 citations for the synthetic control group. This is a difference of no less than $78 \%$. We conjecture that awards, in general, tend to raise productivity, as well as attract more attention from peers.

\section{References}

Abadie, A., \& Diamond, A. J. (2008). Terrorism and the World Economy. European Economic Review, 52(1): 1-27.

Abadie, A., Diamond, A., \& Hainmueller, J. (2010). Synthetic Control Methods for Comparative Case Studies: Estimating the Effect of California's Tobacco Control Program. Journal of the American Statistical Association, 105(490): 493-505.

Abadie, A., Diamond, A. J., \& Hainmueller, J. (2012). Comparative Politics and the Synthetic Control Method. MIT Political Science Department Research Paper No. 2011-25.

Abadie, A., \& Gardeazabal, J. (2003). The Economic Costs of Conflict: A Case Study of the Basque Country. American Economic Review, 93(1): 113132.

Akerlof, G. A. (1976). The Economics of Caste and of the Rat Race and Other Woeful Tales. Quarterly Journal of Economics 90(4): 599-617.

Albert, R. S. (1975). Toward a Behavioral Definition of Genius. American Psychologist, 30(2): 140-151.

Arrow, K. J., Bernheim, B. D., Feldstein, M. S., McFadden, D. L., Poterba, J. M., \& Solow, R. M. (2011). 100 Years of the American Economic Review: The Top 20 Articles. American Economic Review, 101(1): 1-8. 
Auriol, E. and Renault, R. (2008). Status and Incentives. RAND Journal of Economics, 39(1): 305-326.

Azoulay, P., Stuart, T., \& Wang, Y. (2011). Matthew: Effect or Fable? HBS working papers ; 12-049. Cambridge, MA: Harvard Business School.

Baker, G. P., Jensen, M. C., \& Murphy, K. J. (1988). Compensation and Incentives: Practice vs. Theory. Journal of Finance, 43(3): 593-616.

Begent, P. J. \& Chesshyre, H. (1999). The Most Noble Order of the Garter: 650 Years. London: Spink and Son Ltd.

Besley, T. (2005). Notes on Honours (mimeo). London School of Economics.

Bielby, W. T. \& Baron. J. N. (1986). Sex Segregation within Occupations. American Economic Review, 76(2): 43-47.

Billmeier, A., \& Nannicini, T. (2011). Economies in Transition: How Important Is Trade Openness for Growth? Oxford Bulletin of Economics and Statistics, 73(3), 287-314.

Blair, D. W., Cottle, R. L., \& Wallace, M. S. (1986). Faculty Ratings of Major Economics Departments by Citations: An Extension. American Economic Review, 76(1): 264-267.

Bourdieu, P. (1979). La Distinction. Critique Sociale Du Jugement. Paris: Les éditions de minuit.

Bramly, S. (1988). Leonardo. The Artist and the Man. London: Michael Joseph.

Braudy, L. (1986). The Frenzy of Renown: Fame and Its History. New York: Oxford University Press.

Brennan, G. \& Pettit, P. (2004). The Economy of Esteem: An Essay on Civil and Political Economy. Oxford: Oxford University Press. 
Campos, N. F., \& Kinoshita, Y. (2010). Structural Reforms, Financial Liberalization, and Foreign Direct Investment. IMF Staff Papers, 57(2): 326365.

Cavallo, E., Galiani, S., Noy, I., \& Pantano, J. (2010). Catastrophic Natural Disasters and Economic Growth. Inter-American Development Bank, June 2010.

Chan, H. F. \& Torgler, B. (2012). Econometric Fellows and Nobel Laureates in Economics, Economics Bulletin, 32, 3365-3377.

Cole, J., \& Cole, S. (1971). Measuring the Quality of Sociological Research: Problems in the use of the Science Citation Index. American Sociologist, 6, 23-29.

Conley, J. P., Crucini, M. J., Driskill, R. A., \& Onder, A. S. (forthcoming). Incentives and the Effects of Publication Lags on Life Cycle Research Productivity in Economics. Economic Inquiry.

Conroy, M. E., Dusansky, R., Drukker, D., \& Kildegaard, A. (1995). The Productivity of Economics Departments in the U.S.: Publications in the Core Journals. Journal of Economic Literature, 33(4): 1966-1971.

Coupé, T. (2003). Revealed Performances: Worldwide Rankings of Economists and Economics Departments, 1990-2000. Journal of the European Economic Association, 1(6): 1309-1345.

Coupé, T. (2013). Peer review versus citations - An analysis of best paper prizes. Research Policy, 42(1): 295-301.

Coupé, T., Ginsburgh, V., \& Noury, A. (2010). Are leading papers of better quality? Evidence from a natural experiment. Oxford Economic Papers, 62(1): $1-11$. 
Cowen, T. (2000). What Price Fame? Cambridge, MA: Harvard University Press.

Dhungana, S. (2011). Identifying and Evaluating Large Scale Policy Interventions: What Questions Can We Answer? Policy Research Working Paper No. 5918, World Bank.

Diamond, A. M. (1984). An Economic-Model of the Life-Cycle Research Productivity of Scientists. Scientometrics, 6(3): 189-196.

Diamond, A. M. (1989). The Core Journals of Economics. Current Contents, 1, 4-11.

Elster, J. (1983). Sour Grapes: Studies in the Subversion of Rationality. Cambridge: Cambridge University Press.

English, J. F. (2005). The Economy of Prestige. Prizes, Awards, and the Circulation of Cultural Value. Cambridge, Mass.: Harvard University Press.

Frank, R. H. (1985). Choosing the Right Pond: Human Behavior and the Quest for Status. New York: Oxford University Press.

Frank, R. H. \& Cook, P. J. (1995). The Winner-Take-All Society: How More and More Americans Compete for Ever Fewer and Bigger Prizes, Encouraging Economic Waste, Income Inequality, and an Impoverished Cultural Life. New York: Free Press.

Frey, B. S. (2005). Knight Fever - Towards an Economics of Awards. CESifo Working Paper No. 1468. CESifo Group Munich.

Frey, B. S. (2006). Giving and Receiving Awards. Perspectives on Psychological Science, 1(4): 377-388.

Frey, B. S. (2007). Awards as Compensation. European Journal of Management, 4, 6-14. 
Frey, B. S. \& Gallus, J. (2013). Awards are a Special Kind of Signal. Mimeo.

Gavrila, C., Caulkins, J. P., Feichtinger, G., Tragler, G., \& Hartl, R. F. (2005). Managing the Reputation of an Award to Motivate Performance. Mathematical Models of Operations Research, 61, 1-22.

Ginsburgh, V. A. (2003). Awards, Success and Aesthetic Quality in the Arts. Journal of Economic Perspectives, 17(2): 99-111.

Ginsburgh, V. A. (2005). Languages, Genes, and Cultures. Journal of Cultural Economics, 29(1): 1-17.

Ginsburgh, V. A. \& van Ours, J. C. (2003). Expert Opinion and Compensation: Evidence from a Musical Competition. American Economic Review, 93(1): 289-296.

Glejser, H. \& Heyndels, B. (2001). Efficiency and Inefficiency in the Ranking in Competitions: The Case of the Queen Elizabeth Music Contest. Journal of Cultural Economics, 25(2): 109-129.

Hamermesh, D. S., Johnson, G. E., \& Weisbrod, B. A. (1982). Scholarship, Citations and Salaries: Economic Rewards in Economics. Southern Economic Journal, 49(2): 472-481.

Hamermesh, D. S. \& Schmidt, P. J. (2003). The Determinants of Econometric Society Fellows Elections. Econometrica, 71(1), 399-407.

Hansen, W.L. \& Weisbrod, B. (1972). Towards a General Theory of Awards, or, Do Economists Need a Hall of Fame? Journal of Political Economy, 80(2): 422-431.

Hansen, W. L., Weisbrod, B. A., \& Strauss, R. P. (1978). Modeling the Earnings and Research Productivity of Academic Economists. Journal of Political Economy, 86(4): 729-741. 
Holden, A. (1993). The Oscars: The Secret History of Hollywood's Academy Awards. London: Little Brown.

Hollis, A. (2001). Co-authorship and the Output of Academic Economists. Labour Economics, 8(4): 503-530.

Holmstrom, B. \& Milgrom, P. (1994). The Firm as an Incentive System. American Economic Review, 84(4): 972-991.

House of Commons, Select Committee on Public Administration (2004). A Matter of Honour: Reforming the Honours System. Fifth Report of Session 2003-04 (Vol. 1). London: Stationary Office.

Huberman, B., Loch, C. H., \& Öncüler, A. (2004). Status as a Valued Resource. Social Psychology Quarterly, 67, 103-114.

Iacus, S. M., King, G., \& Porro, G. (2011). Multivariate Matching Methods That Are Monotonic Imbalance Bounding. Journal of the American Statistical Association, 106(493): 345-361.

Johnston, D., W., Piatti, M., \& Torgler, B. (forthcoming). Citation Success Over Time: Theory or Empirics? Scientometrics.

Kalaitzidakis, P., Mamuneas, T. P., \& Stengos, T. (2011). An Updated Ranking of Academic Journals in Economics. Canadian Journal of Economics-Revue Canadienne D'Economique, 44(4): 1525-1538.

Koczy, L. A., \& Strobel, M. (2010). The World Cup of Economics Journals: A Ranking by a Tournament Method, Institute of Economics, Hungarian Academy of Sciences.

Kodrzycki, Y. K., \& Yu, P. (2006). New Approaches to Ranking Economics Journals. B.E. Journal of Economic Analysis \& Policy, 5(1), Article 24. 
Kosfeld, M., \& Neckermann, S. (2011). Getting More Work for Nothing? Symbolic Awards and Worker Performance. American Economic JournalMicroeconomics, 3(3): 86-99.

Laband, D. N., \& Piette, M. J. (1994). Favoritism Versus Search for Good Papers: Empirical Evidence Regarding the Behavior of Journal Editors. Journal of Political Economy, 102(1): 194-203.

Levy, E. (1987). And the Winner Is... The History and Politics of the Oscar Awards. New York: Ungar.

Liebowitz, S. J., \& Palmer, J. P. (1984). Assessing the Relative Impacts of Economics Journals. Journal of Economic Literature, 22(1): 77-88.

Lindsey, D. (1980). Production and Citation Measures in the Sociology of Science: The Problem of Multiple Authorship. Social Studies of Science, 10(2): 145-162.

Liou, Y.-M., \& Musgrave, P. (2012). Resource Wealth Is an Amplifier, not a Curse: Evidence from Country-Level Effects of Exogenous Variation in Resource Endowments. Mortara Working Paper No. 2012-1, Georgetown University.

Long, J. S., \& McGinnis, R. (1982). On Adjusting Productivity Measures for Multiple Authorship. Scientometrics, 4(5): 379-387.

Magnus, M. (1981). Employee Recognition: A Key to Motivation. Personnel Journal, (February), 103-107.

Malmendier, U. \& Tate, G. (2009). Superstar CEOs. The Quarterly Journal of Economics, 124(4): 1593-1638.

Markham, S. E., Scott, K. D., \& McKee, G. H. (2002). Recognizing Good Attendance: A Longitudinal, Quasi-experimental Field Study. Personnel Psychology, 55(3): 639-660. 
Martin, S. (2007). The Order of Merit: One Hundred Years of Matchless Honour. London, New York, NY: I.B. Tauris \& Co. Ltd.

Mazloumian, A., Eom, Y.-H., Helbing, D., Lozano, S., \& Fortunato, S. (2011). How Citation Boosts Promote Scientific Paradigm Shifts and Nobel Prizes. PLoS ONE, 6(5): e18975. doi:10.1371/journal.pone.0018975.

Medoff, J. L., \& Abraham, K. G. (1981). Are Those Paid More Really More Productive? The Case of Experience. Journal of Human Resources, 16(2): 186-216.

Merton, R. K. (1973). The Sociology of Science: Theoretical and Empirical Investigations. Chicago: University of Chicago Press.

Montalvo, J. G. (2011). Voting after the Bombings: A Natural Experiment on the Effect of Terrorist Attacks on Democratic Elections. Review of Economics and Statistics, 93(4): 1146-1154.

Nalebuff, B. J. \& Stiglitz, J. E. (2001). Prizes and Incentives: Towards a General Theory of Compensation and Competition. Bell Journal of Economics, 14(1): 21-43.

Neckermann, S., Cueni, R., \& Frey, B. S. (2012). Awards at Work. ZEW Centre for European Economic Research Discussion Paper No. 12-004.

Nelson, B. (2005). 1001 Ways to Reward Employees. New York: Workman Publishing.

Nelson, R. A., Donihue, M. R., Waldman, D., \& Wheaton, C. (2001). What's an Oscar Worth? Economic Inquiry, 39(1): 1-16.

Nilakantan, R., \& Singhal, S. (2012). Naxalite Insurgency and the Economic Benefits of a Unique Robust Security Response (mimeo). 
Palacios-Huerta, I., \& Volij, O. (2004). The Measurement of Intellectual Iinfluence. Econometrica, 72(3): 963-977.

Phillips, S. H. (2004). Review of the Honours System. London: Cabinet Office.

Piatti, M. (2012). Selected Essays in Competitive Environments, Master of Business Thesis, Queensland University of Technology.

Pinotti, P. (2011). The Economic Consequences of Organized Crime: Evidence from Southern Italy, mimeo.

Ritzberger, K. (2008). A Ranking of Journals in Economics and Related Fields. German Economic Review, 9(4): 402-430.

Samuelson, P. A. (2004). Paul A. Samuelson. In W. Breit \& B. T. Hirsch (Eds.), Lives of the Laureates: Eighteen Nobel Economists (pp. 49-64). Cambridge, Mass.: MIT Press.

Sanso-Navarro, M. (2011). The effects on American foreign direct investment in the United Kingdom from not adopting the euro. Journal of Common Market Studies, 49(2): 463-483.

Scitovsky, T. (1976). The Joyless Economy: An Inquiry into Human Satisfaction and Consumer Dissatisfaction. New York: Oxford University Press.

Simonton, D. K. (2004). Film Awards as Indicators of Cinematic Creativity and Achievement: A Quantitative Comparison of the Oscars and Six Alternatives. Creativity Research Journal, 16(2): 163-172.

Stigler, G. J., \& Friedland, C. (1975). The Citation Practices of Doctorates in Economics. Journal of Political Economy, 83(3): 477-507.

Stigler, G. J., \& Friedland, C. (1979). The Pattern of Citation Practices in Economics. History of Political Economy, 11(1): 1-20. 
Sutter, M., \& Kocher, M. G. (2001). Tools for Evaluating Research Output: Are Citation-based Rankings of Economics Journals Stable? Evaluation Review, 25(5): 555-566.

Torgler, B., \& Piatti, M. (2011). A Century of American Economic Review. CREMA Working Paper No. 2011-04.

Tuckman, H. P., \& Leahey, J. (1975). What Is an Article Worth? Journal of Political Economy, 83(5): 951-968.

van Dalen, H. P., \& Klamer, A. (2005). Is Science a Case of Wasteful Competition? Kyklos, 58(3): 395-414.

Wade, J. B., Porac, J. F., Pollock, T. G. \& Graffin, S. D. 2006. The burden of celebrity: The impact of CEO certification contests on CEO pay and performance. Academy of Management Journal, 49(4): 643-660.

Walzer, M. (1983). Spheres of Justice: A Defense of Pluralism and Equality. New York: Basic Books. 


\section{Appendix A}

\section{TABLE A1: JoURnAl CONTENT}

\begin{tabular}{|c|c|c|c|c|c|}
\hline Journal & $\begin{array}{c}\text { Year established } \\
\text { (first year } \\
\text { available) }\end{array}$ & $\begin{array}{c}\text { Number of } \\
\text { articles }\end{array}$ & $\begin{array}{c}\text { Number of } \\
\text { unique } \\
\text { authors }\end{array}$ & $\begin{array}{c}\text { Number } \\
\text { of } \\
\text { articles } \\
\text { per } \\
\text { available } \\
\text { years }\end{array}$ & $\begin{array}{c}\text { Number } \\
\text { of } \\
\text { authors } \\
\text { per } \\
\text { available } \\
\text { years }\end{array}$ \\
\hline American Economic Review & 1911 & 6313 & 5580 & 61.89 & 54.71 \\
\hline $\begin{array}{l}\text { Brookings Papers on Economic } \\
\text { Activity }\end{array}$ & 1970 & 3388 & 2645 & 42.35 & 33.06 \\
\hline Econometric Theory & $1985(1988)$ & 3535 & 2643 & 80.34 & 60.07 \\
\hline Econometrica & 1933 & 4737 & 3794 & 41.55 & 33.28 \\
\hline Economic Journal & 1900 & 2706 & 2406 & 34.25 & 30.46 \\
\hline Games and Economic Behavior & $1989(1991)$ & 3892 & 3258 & 34.14 & 28.58 \\
\hline International Economic Review & $1960 *$ & 1928 & 1845 & 52.11 & 49.86 \\
\hline $\begin{array}{l}\text { Journal of Business \& Economic } \\
\text { Statistics }\end{array}$ & $1983(1985)$ & 2894 & 2599 & 87.70 & 78.76 \\
\hline Journal of Econometrics & $1973(1980)$ & 4480 & 4010 & 66.87 & 59.85 \\
\hline Journal of Economic Literature & $1963(1969)$ & 1689 & 1753 & 73.43 & 76.22 \\
\hline $\begin{array}{l}\text { Journal of Economic } \\
\text { Perspectives }\end{array}$ & $1987(1988)$ & 1922 & 2131 & 51.95 & 57.59 \\
\hline Journal of Economic Theory & 1969 & 1633 & 1716 & 39.83 & 41.85 \\
\hline Journal of Finance & 1946 & 640 & 559 & 15.24 & 13.31 \\
\hline Journal of Financial Economics & $1974(1976)$ & 1284 & 942 & 51.36 & 37.68 \\
\hline Journal of Law and Economics & 1958 & 4237 & 3682 & 37.50 & 32.58 \\
\hline Journal of Monetary Economics & 1976 & 1958 & 2210 & 46.62 & 52.62 \\
\hline Journal of Political Economy & $1892(1899)$ & 1171 & 1620 & 41.82 & 57.86 \\
\hline Journal of Public Economics & 1976 & 624 & 717 & 14.18 & 16.30 \\
\hline Quarterly Journal of Economics & $1886(1899)$ & 1132 & 1281 & 45.28 & 51.24 \\
\hline RAND Journal of Economics & 1970 & 1113 & 1235 & 20.61 & 22.87 \\
\hline Review of Economic Studies & 1933 & 2820 & 2989 & 76.22 & 80.78 \\
\hline
\end{tabular}




\begin{tabular}{|c|c|c|c|c|c|}
\hline & 1919 & 4410 & 4705 & 67.85 & 72.38 \\
\hline Review of Financial Studies & $1988(1990)$ & 1184 & 1545 & 51.48 & 67.17 \\
\hline \multicolumn{6}{|c|}{$\begin{array}{l}\text { Note: Besides the missing records for the first few years of certain journals, Web of Science } \\
\text { does not have records for International Economic Review for the period between } 1966 \text { and } \\
\text { 1976. Additionally, we exclude American Economic Review Papers and Proceedings. These } \\
\text { missing data do create some problems in our analysis. For example, one John Bates Clark } \\
\text { medalist, Daniel L. McFadden, the recipient in 1975, has two articles in the Journal of Public } \\
\text { Economics in } 1974 \text { that are not recorded in our dataset, which might give a false reflection of } \\
\text { the medalist's true quality, and therefore create an inappropriate/inaccurate synthetic control } \\
\text { group. }\end{array}$} \\
\hline
\end{tabular}

\section{TABlE A2: JouRnAl RANKINGS AND ASSOCIATED QUALITY ADJUSTMENT INDEX}

\begin{tabular}{|c|c|c|c|c|c|c|c|c|c|}
\hline Journal & $\begin{array}{c}\text { KY } \\
(2006)\end{array}$ & $\begin{array}{l}\text { KMS } \\
(2011)\end{array}$ & $\begin{array}{c}\text { CCOD } \\
\text { (forthcomi } \\
\text { ng) }\end{array}$ & $\begin{array}{c}\text { LP } \\
(1984)\end{array}$ & $\begin{array}{l}\text { PHV } \\
(2004)\end{array}$ & $\begin{array}{c}\text { Ritzberger } \\
\text { (2008) }\end{array}$ & $\begin{array}{c}\text { KS } \\
(2010)\end{array}$ & $\begin{array}{l}\text { Simple } \\
\text { average }\end{array}$ & $\begin{array}{c}\# \text { of } \\
\text { appearanc } \\
\text { es in top } \\
10 \\
\text { ranking }\end{array}$ \\
\hline $\begin{array}{l}\text { American Economic } \\
\text { Review }\end{array}$ & 1 & 1 & 1 & 1 & 0.759 & 0.361 & 0.964 & 0.869 & 7 \\
\hline Econometrica & 0.799 & 0.448 & 0.968 & 0.64 & 1 & 1 & 0.993 & 0.835 & 7 \\
\hline $\begin{array}{l}\text { Journal of Economic } \\
\text { Theory }\end{array}$ & 0.421 & 0.225 & 0.588 & 0.226 & 0.344 & 0.346 & 0.934 & 0.441 & 7 \\
\hline $\begin{array}{l}\text { Journal of Political } \\
\text { Economy }\end{array}$ & 0.746 & 0.414 & 0.652 & 0.809 & 0.669 & 0.513 & 1 & 0.686 & 7 \\
\hline $\begin{array}{l}\text { Review of Economic } \\
\text { Studies }\end{array}$ & 0.404 & 0.327 & 0.452 & 0.225 & 0.643 & 0.530 & 0.961 & 0.506 & 7 \\
\hline $\begin{array}{l}\text { Quarterly Journal of } \\
\text { Economics }\end{array}$ & 0.884 & 0.596 & 0.581 & 0.001 & 0.988 & 0.724 & 0.982 & 0.679 & 6 \\
\hline $\begin{array}{l}\text { Journal of Monetary } \\
\text { Economics }\end{array}$ & 0.333 & 0.278 & 0.364 & 0.23 & 0.461 & 0.379 & 0.857 & 0.415 & 5 \\
\hline Journal of Econometrics & 0.359 & 0.162 & 0.549 & 0.16 & 0.212 & 0.260 & 0.840 & 0.363 & 4 \\
\hline Journal of Finance & 0.987 & . & . & 0.174 & . & 0.383 & . & 0.515 & 3 \\
\hline $\begin{array}{l}\text { Games and Economic } \\
\text { Behavior }\end{array}$ & 0.226 & 0.120 & 0.355 & . & 0.326 & 0.212 & 0.609 & 0.308 & 2 \\
\hline
\end{tabular}




\begin{tabular}{|c|c|c|c|c|c|c|c|c|c|}
\hline $\begin{array}{l}\text { Journal of Financial } \\
\text { Economics }\end{array}$ & 0.787 & 0.157 & 0.099 & . & 0.150 & 0.310 & 0.930 & 0.406 & 2 \\
\hline $\begin{array}{l}\text { RAND Journal of } \\
\text { Economics }\end{array}$ & 0.205 & 0.130 & 0.114 & . & 0.201 & 0.141 & 0.913 & 0.284 & 2 \\
\hline $\begin{array}{l}\text { Brookings Papers on } \\
\text { Economic Activity }\end{array}$ & 0.135 & 0.051 & . & . & . & . & 0.939 & 0.375 & 1 \\
\hline Econometric Theory & 0.115 & 0.036 & 0.459 & 0.118 & 0.564 & 0.161 & & 0.242 & 1 \\
\hline Economic Journal & 0.248 & 0.208 & 0.207 & 0.168 & 0.858 & 0.119 & 0.096 & 0.272 & 1 \\
\hline $\begin{array}{l}\text { International Economic } \\
\text { Review }\end{array}$ & 0.266 & 0.124 & 0.230 & 0.394 & 0.856 & 0.156 & 0.190 & 0.317 & 1 \\
\hline $\begin{array}{l}\text { Journal of Business \& } \\
\text { Economic Statistics }\end{array}$ & 0.176 & 0.069 & 0.384 & 0.177 & 0.786 & . & . & 0.318 & 1 \\
\hline $\begin{array}{l}\text { Journal of Economic } \\
\text { Literature }\end{array}$ & 0.354 & 0.183 & 0.188 & . & 0.864 & 0.786 & . & 0.475 & 1 \\
\hline $\begin{array}{l}\text { Journal of Economic } \\
\text { Perspectives }\end{array}$ & 0.318 & 0.192 & 0.343 & . & 0.894 & . & . & 0.437 & 1 \\
\hline $\begin{array}{l}\text { Journal of Law and } \\
\text { Economics }\end{array}$ & 0.056 & 0.035 & 0.039 & 0.112 & 0.913 & . & . & 0.231 & 1 \\
\hline $\begin{array}{l}\text { Journal of Public } \\
\text { Economics }\end{array}$ & 0.247 & 0.222 & 0.198 & 0.171 & 0.753 & 0.163 & 0.121 & 0.268 & 1 \\
\hline $\begin{array}{l}\text { Review of Economics } \\
\text { and Statistics }\end{array}$ & 0.315 & 0.242 & 0.280 & 0.201 & 0.911 & 0.163 & 0.115 & 0.318 & 1 \\
\hline $\begin{array}{l}\text { Review of Financial } \\
\text { Studies }\end{array}$ & 0.480 & . & . & 0.304 & . & . & . & 0.392 & 1 \\
\hline
\end{tabular}

Note: We standardize the indices by dividing all values by the highest score (see Koczy \& Strobel, 2010; Palacios-Huerta \& Volij, 2004), so that the highest-quality journal receives a value of 1 . 


\section{TABLE A3: RANKING METHODS}

\begin{tabular}{lll}
\hline \hline Ranking & Index Reference & Index title
\end{tabular}

\section{LP Method}

\begin{tabular}{lll}
\hline Kodrzycki \& Yu (2006) & $\begin{array}{l}\text { p.22-27, table 2, } \\
\text { column 1 }\end{array}$ & Within Economics Impact \\
$\begin{array}{l}\text { Kalaitzidakis, Mamuneas \& } \\
\text { ptengos (2011) }\end{array}$ & $\begin{array}{l}\text { column 2 } \\
\text { p.80-81, table 1, table 1, }\end{array}$ & Citation/Article Index \\
Liebowitz and Palmer & column 3 & Citations to Articles Published 1975- \\
(1984) & & 1979 \\
& p.32, table A.3 & \\
Conley et al. (forthcoming) & & \\
Invariant method & & \\
\hline Palacios-Huerta \& Volij & p.972, table 1, & Invariant Method \\
(2004) & column 1 & \\
Ritzberger (2008) & p.413-418, table 1, & Value \\
& column 1
\end{tabular}

\section{Tournament method}

Koczy \& Strobel (2010) p.13-19, table 1


TABle A4: JoHn BATES Clark Medalists

\begin{tabular}{|c|c|c|}
\hline John Bates Clark Medalists & Year Awarded & Year of Birth \\
\hline Paul A Samuelson & 1947 & 1915 \\
\hline Kenneth E. Boulding & 1949 & 1910 \\
\hline Milton Friedman & 1951 & 1912 \\
\hline James Tobin & 1955 & 1918 \\
\hline Kenneth J. Arrow & 1957 & 1921 \\
\hline Lawrence R. Klein & 1959 & 1920 \\
\hline Robert M. Solow & 1961 & 1924 \\
\hline Hendrik S. Houthakker & 1963 & 1924 \\
\hline Zvi Griliches & 1965 & 1930 \\
\hline Gary S. Becker & 1967 & 1930 \\
\hline Marc Nerlove & 1969 & 1933 \\
\hline Dale W. Jorgenson & 1971 & 1933 \\
\hline Franklin M. Fisher & 1973 & 1934 \\
\hline Daniel L. McFadden & 1975 & 1937 \\
\hline Martin S. Feldstein & 1977 & 1939 \\
\hline Joseph E. Stiglitz & 1979 & 1943 \\
\hline A. Michael Spence & 1981 & 1943 \\
\hline James J. Heckman & 1983 & 1944 \\
\hline Jerry A. Hausman & 1985 & 1946 \\
\hline Sanford J. Grossman & 1987 & 1953 \\
\hline David M. Kreps & 1989 & 1950 \\
\hline Paul R. Krugman & 1991 & 1953 \\
\hline Lawrence H. Summers & 1993 & 1954 \\
\hline David Card & 1995 & 1956 \\
\hline Kevin M. Murphy & 1997 & 1958 \\
\hline Andrei Shleifer & 1999 & 1961 \\
\hline Matthew Rabin & 2001 & 1963 \\
\hline
\end{tabular}

Notes: The list of all the John Bates Clark medalists is provided by the American Economic Association, see http://www.aeaweb.org/honors_awards/clark_medal.php. 
TABLE A5: SyNTHETIC CONTROL GROUP FOR ANDREI SHLEIFER

\begin{tabular}{lclll}
\hline \hline Name & Weight & PhD Institution & $\begin{array}{l}\text { PhD } \\
\text { Year }\end{array}$ & $\begin{array}{l}\text { Year of } \\
\text { Birth }\end{array}$ \\
\hline Andrei Shleifer & & MIT & $\mathbf{1 9 8 6}$ & $\mathbf{1 9 6 1}$ \\
\hline N. Gregory & & & 1984 & 1958 \\
Mankiw & 0.252 & MIT & 1980 & 1953 \\
Kenneth S. Rogoff & 0.198 & MIT & 1981 & 1953 \\
Jean Tirole & 0.197 & MIT & 1982 & 1955 \\
$\begin{array}{l}\text { Donald W. K. } \\
\text { Andrews }\end{array}$ & 0.132 & University of California, & & \\
Julio J. Rotemberg & 0.109 & Princeton University & 1981 & 1953 \\
$\begin{array}{l}\text { R. Preston } \\
\text { McAfee }\end{array}$ & 0.083 & Purdue University & 1980 & 1956 \\
Carl Shapiro & 0.029 & MIT & 1981 & 1955 \\
\hline
\end{tabular}




\section{Appendix B}

FIGURE B1: ANDREI SHLEIFER AND HIS SYNTHETIC CONTROL UNIT

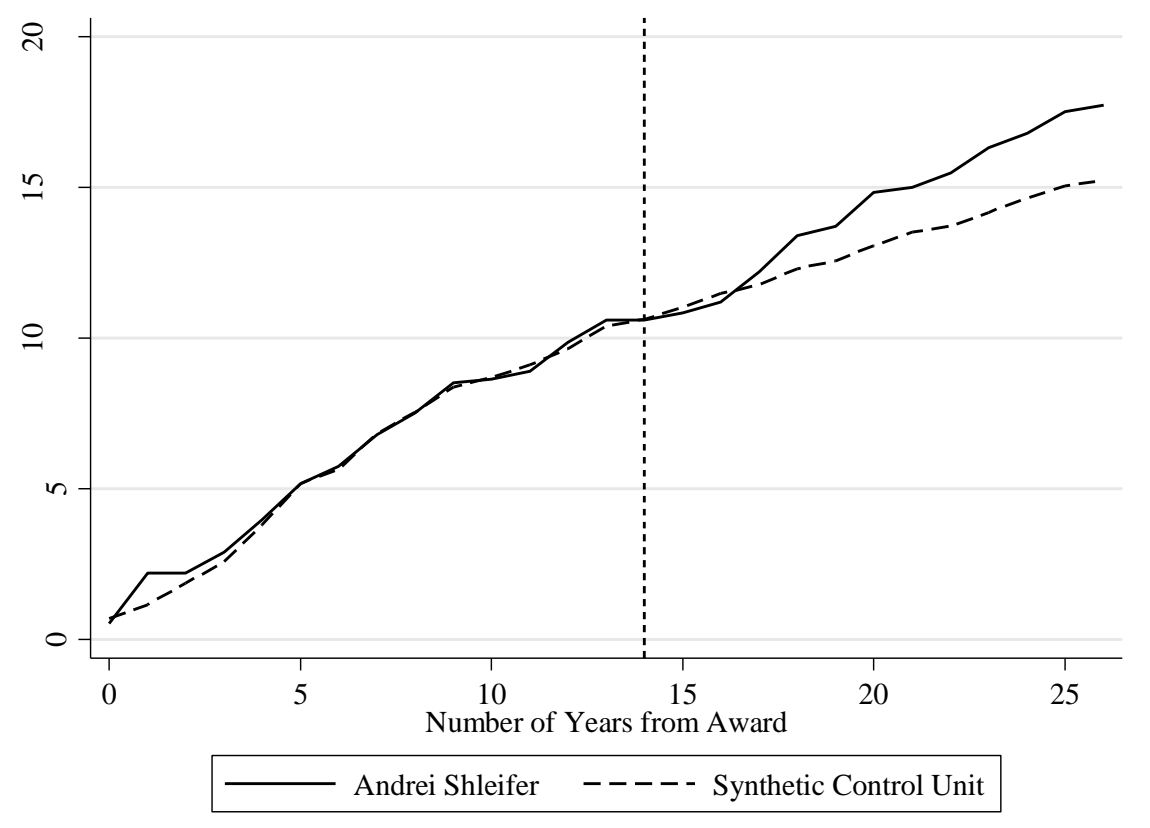

Figure B2: Number of Publications AND CitATIONS PER Publication

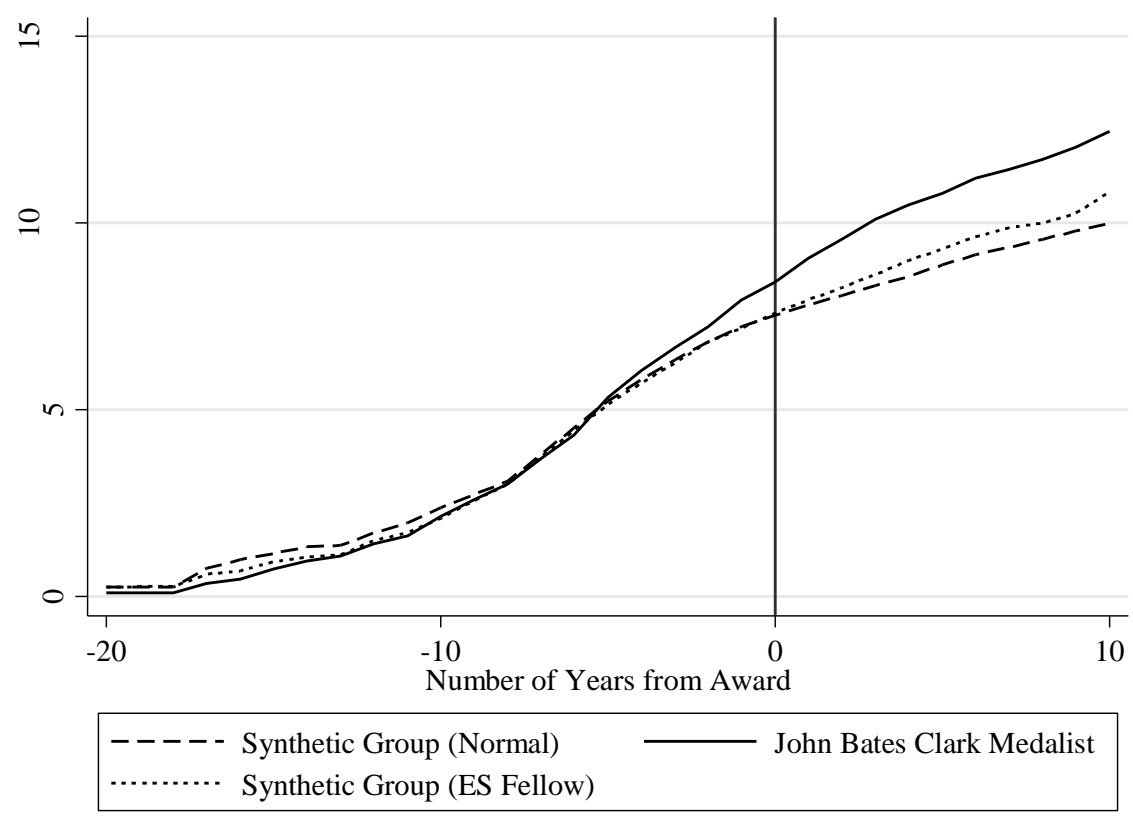




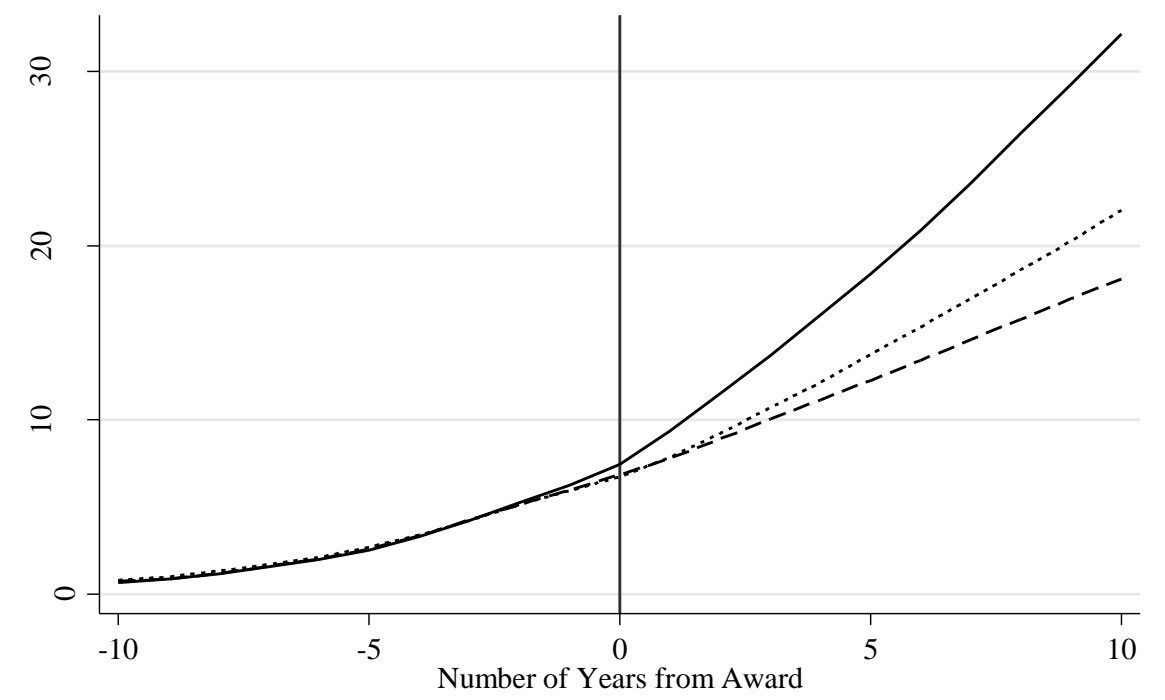

- - - - Synthetic Group (Normal)

John Bates Clark Medalist 